\title{
Pengelolaan Keuangan Desa : Studi Pada Desa Ploso Kecamatan Jombang Tahun Anggaran 2012-2016
}

\author{
Andrianto \\ Fakultas Ekonomi, Universitas Muhammadiyah Surabaya \\ Email: andrianto914@yahoo.com
}

\begin{abstract}
With the enactment of Law No. 6 of 2014 on villages, it is desirable that in the management of the village, especially in the management of its finances, it can be done accountably and responsibly. This study aims to identify the financial management of the village along with the problems associated with the management of village finances conducted in the Village Ploso Jombang. This research uses qualitative method with case study approach, where most of the research implementation mostly use observation and interview method. The results show that in the management of village finances there are main issues that is the lack of knowledge of village head and its officials in the management of budget and village finances. This research proposes the existence of computerized system accompanied by training and guidance of village financial management from local government apparatus, so it is expected that village financial reporting can be done by fast process and with output of accountable and accountable financial statement.
\end{abstract}

Keywords: Village Finance, Financial Reporting, Accountable.

\begin{abstract}
Abstrak
Dengan mulai diberlakukannya Undang-undang nomor 6 tahun 2014 tentang desa, menghendaki agar dalam pengelolaan desa terutama dalam pengelolaan keuangannya dapat dilakukan secara akuntabel dan bertanggung jawab. Penelitian ini bertujuan untuk mengidentifikasi pengelolaan keuangan desa beserta permasalahannya terkait dengan pengelolaaan keuangan desa yang dilakukan di Desa Ploso Kabupaten Jombang. Penelitian ini menggunakan metode kualitatif dengan pendekatan studi kasus, dimana sebagian besar pelaksanaan penelitian banyak menggunakan metode observasi dan wawancara. Hasil penelitian menunjukkan bahwa dalam pengelolaan keuangan desa terdapat pokok permasalahan yang utama yaitu minimnya pengetahuan kepala desa beserta aparatnya dalam pengelolaan anggaran dan keuangan desa. Penelitian ini mengusulkan adanya sistem terkomputerisasi disertai dengan pelatihan dan bimbingan pengelolaan keuangan desa dari aparat pemerintah daerah,sehingga diharapkan pelaporan keuangan desa dapat dilakukan dengan proses yang cepat dan dengan output laporan keuangan yang akuntabel dan dapat dipertanggung jawabkan.
\end{abstract}

Kata kunci: Keuangan Desa, Pelaporan Keuangan, Akuntabel. 


\section{Pendahuluan}

Penyelenggaraan otonomi daerah membawa perubahan pada sistem pelaksanaan pemerintah daerah. Wilayah Indonesia yang begitu luas dengan sumber daya yang berbedabeda dan begitu melimpah ruah dari darat, laut dan udara membawa pengaruh yang besar pada pengelolaan otonomi daerah. Tentunya hal ini akan berdampak pengaruh yang besar bagi keberhasilan dalam pengelolaan otonomi daerah. Dengan adanya Undang-undang Nomor 32 Tahun 2004 tentang Pemerintah Daerah,Pemerintah Pusat telah memberikan kepada pemerintah daerah kewenangan yang cukup luas,nyata dan bertanggung jawab. Maksud dari pengertian ini adalah bahwa pemerintah pusat telah memberikan kesempatan kepada masing-masing daerah dalam mengatur dan melaksanakan kebijakannya sendiri dalam mengelola pembangunan daerahnya sesuai dengan kepentingan dan kesejahteraan masyarakat daerah setempat.

Salah satu dampak positif dari pelaksanaan otonomi daerah ini adalah terjadinya perubahan pada sistem pemerintahan yang sebelumnya dari sentralistik ke sistem desentralistik (Kindarsih, 2008) Salah satu sektor yang perlu mendapat perhatian lebih tersebut adalah desa. Desa merupakan merupakan unit terkecil dalam susunan unit organisasi pemerintahan yang berfungsi memberikan pelayanan langsung kepada masyarakat, misalnya pelayanan administratif, kependudukan, pernikahan, kematian dan lain-lain. Selain itu dalam pemerintahan desa, desa mempunyai peran penting dalam membantu proses penyelenggaraan pemerintah dan pembangunan daerah. Terbatasnya alokasi dana dari pemerintah adalah salah satu kendala yang dapat menurunkan pelayanan kepada masyarakat dan penurunan tatanan ekonomi masyarakat desa.

Untuk memperkuat dalam pengelolaan dana desa tersebut, pemerintah telah melahirkan undang-undang yang mengatur segala hal dalam pengaturan dan kewenangannya beserta turunannya. Dengan lahirnya Undang-undang Nomor 6 Tahun 2014 membawa kabar gembira bagi desa. Sayangnya, dari lahirnya undang-undang ini hanya dipahami secara sempit dengan adanya pengucuran dana dari berbagai sumber ke Desa. Dengan adanya UU beserta turunannya tersebut Desa diberikan kesempatan untuk menjadi berdaya,sejahtera, dan mandiri. Hal ini dikarenakan UU beserta turunannya tidak 
hanya mengatur mengenai keuangan Desa, tetapi juga kewenangan Desa, Kelembagaan Desa, peraturan di Desa, pembangunan Desa, dan pembangunan kawasan perdesaan, administrasi Desa, aset Desa, dan Badan Usaha Milik Desa.

Kondisi aparatur pemerintah daerah saat ini masih tergolong memiliki kemampuan yang rendah terutama dalam hal pengelolaan keuangan daerah dan pencatatan akuntansinya. Pada tataran pertanggung jawaban pengelolaan administrasi pencatatan akuntansi atas keuangan desa,kompetensi sumber daya manusia di desa merupakan kendala utama. Desa Ploso merupakan salah satu desa yang terletak dalam wilayah Kecamatan Jombang, yang dimana telah memiliki kewenangan untuk mengatur pemerintahan sendiri seperti tertuang dalam Peraturan Pemerintah Republik Indonesia dalam undang-undang nomor6 tahun 2014 tentang Desa serta Peraturan Pemerintah Menteri Dalam Negeri Nomor 113 Tahun 2014 tentang pengelolaan keuangan Desa.

Peraturan -peraturan tersebut menjadi pedoman bagi pemerintahan desa ploso dalam pencatatan dan pengelolaan keuangan desa. Namun, seperti yang telah disampaikan diatas bahwa kondisi aparatur desa yang masih memiliki kemampuan yang rendah terutama dalam hal untuk kegiatan pencatatan, pelaporan dan penatausahaan kegiatan akuntansi sehingga dapat menghasilkan informasi keuangan/ laporan keuangan yang tepat waktu, menjadi kendala bagi pemerintahan desa Ploso saat ini. Tentunya hal ini, menjadi suatu pertimbangan keputusan bagi Kepala Desa, bagaimana meningkatkan kualitas pengetahuan aparatur desa terutama kualitas yang berkaitan dengan pencatatan akuntansi sehingga dapat menghasilkan pelaporan informasi keuangan yang tepat waktu dan dapat digunakan untuk pengambilan keputusan bagi organisasi.

Dari uraian diatas, penulis tertarik untuk melakukan penelitian terkait dengan akuntansi desa berdasarkan peraturan-peraturan diatas. Penulis mengambil judul dalam penelitian ini "Pengelolaan Keuangan Desa : Studi pada Desa Ploso Kecamatan Jombang Tahun Anggaran 2012 - 2016".

\section{Tujuan Penelitian}

Untuk mengetahui bagaimana Pengelolaan Keuangan Desa : studi pada Desa Ploso Kecamatan Jombang Tahun Anggaran 2012 -2016. 


\section{Penelitian Terdahulu}

Berbagai penelitian yang telah dilakukan oleh para peneliti terdahulu terkait dengan kualitas pencatatan pelaporan keuangan sektor publik di Indonesia :

1. Harun ( 2007) menyatakan tentang pentingnya peningkatan kualitas akuntansi sektor publik di Indonesia, organisasi Pemerintah,seperti layaknya perusahaan swasta besar, memerlukan informasi keuangan / laporan keuangan yang tepat waktu dan akurat untuk tujuan organisasi.

2. Akbar (2011) menyimpulkan akuntabilitas publik dan keterbukan merupakan dua sisi koin yang tidak terpisahkan sebagai bagian dari prinsip -prinsip tata pemerintahan yang baik (good governance).

3. Tanjung (2000) juga menyatakan bahwa Laporan keuangan pemerintah daerah yang dihasilkan melalui proses akuntansi merupakan bentuk transparansi dan akuntabilitas pengelolaan keuangan publik. Oleh karena itu, untuk dapat menghasilkan laporan keuangan yang semakin baik (tantangan) dibutuhkan tenaga-tenaga akuntansi terampil pada pemerintah daerah, hal ini dapat dilakukan melaui kegiatan bimbingan teknis akuntansi bagi pegawai pemerintah daerah yang ditugaskan sebagai pengelola keuangan atau melalui rekrutmen pegawai baru yang memiliki kemampuan akuntansi keuangan daerah.

4. Yahya (2006) juga memberikan kesimpulan yang seirama bahwa proses dalam informasi akuntansi dan laporan keuangan daerah adalah merupakan sarana akuntabilitas dan transparansi keuangan dan kualitas pemerintahan daerah yang baik (good governance) sangat ditentukan oleh akuntabilitas,transparansi pengelolaan keuangannya.

5. Sadjiarto (2000) menyatakan bahwa good governance dan akuntabilitas pemerintahan di Indonesia sangat ditentukan dari pengelolaan keuangannya.

6. Furqani (2010) menyimpulkan ada korelasi positif antara pengelolaan keuangan yang baik dengan upaya untuk mewujudkan good governance.

7. Aliyah dan Nahar (2012) menyatakan bahwa penyajian laporan keuangan daerah berpengaruh positif dan signifikan terhadap transparansi dan akuntabilitas pengelolaan keuangan daerah. Penyajian laporan keuangan daerah secara lengkap yang sesuai dengan standar akuntansi pemerintahan dan mudah diakses oleh semua pihak yang 
berkepentingan memungkinkan kontrol dan pengawasan terhadap pengelolaan keuangan bisa berjalan dengan baik.

8. Demikian juga, penelitian yang dilakukan oleh Yuliani et al (2010) menyatakan bahwa pemahaman akuntansi berpengaruh terhadap kualitas laporan keuangan pemerintah kota.

\section{Metode}

\section{Ruang Lingkup Penelitian}

Adapun yang menjadi ruang lingkup penelitian ini adalah pada kegiatan -kegiatan yang berhubungan dengan kegiatan pengelolaan keuangan desa meliputi pendapatan dan belanja desa pada pemerintahan desa ploso yang merupakan bagian dari wilayah kecamatan Jombang.

\section{Pendekatan Penelitian dan Data Penelitian}

Dalam melakukan penelitian ini, penulis menggunakan metode penelitian kualitatif dengan pendekatan studi kasus yang mendeskripsikan terhadap sumber-sumber APBD Desa dan digunakan untuk apa saja dalam pelaksanaannya dengan mengambil kasus yang terjadi di lapangan pada Pemerintahan Desa Ploso yang merupakan salah satu kabupaten Jombang Jawa Timur.

Sedangkan data penelitian yang digunakan dalam penelitian ini adalah data primer dan data sekunder. Adapun data primer merupakan data yang bersumber langsung dari informan pada objek peneliti yang telah terjun ke lapangan dengan melakukan wawancara pada bagian penata usaha keuangan pada aparatur Desa Ploso dan kemudian melakukan observasi terhadap angka-angka keuangan yang menjadi target dan realisasi pada pendapatan dan belanja desa. Sedangkan data sekunder pada penelitian ini berupa data data yang berisi dokumen-dokumen keuangan pemerintah Desa Ploso, serta data-data yang bersumber dari buku-buku referensi dan jurnal-jurnal yang berkaitan dengan penelitian ini. 


\section{Prosedur Pengumpulan Data}

Prosedur pengumpulan data merupakan tahapan-tahapan atau langkah-langkah yang harus dilalui oleh peneliti bila akan melakukan penelitian. Yang dimaksud tahapan disini adalah tahapan pengumpulan data, informasi, keterangan dari responden yang akan diolah dalam penelitian (Fatihuddin, 2015). Prosedur pengumpulan data yang dilakukan dalam penelitian ini dilakukan dengan tahapan-tahapan langkah sebagai berikut :

1. Wawancara, dengan melakukan wawancara langsung kepada aparatur desa pada bagian bendahara serta sebagai tambahan informasi dalam penelitian ini, penulis juga melakukan wawancara kepada Kepala Desa Ploso, untuk mendapatkan informasi dengan pengelolaan keuangan desa mulai dari perencanaan hingga sampai pada pelaporannya.

2. Observasi, mendapatkan data dengan cara mengadakan pengamatan secara langsung kepada objek penelitian yaitu pemerintahan Desa Ploso Kecamatan Jombang.

\section{Hasil dan Pembahasan}

\section{Hasil wawancara}

Wawancara telah dilakukan dengan berbagai pihak yang telah disebutkan oleh penulis pada bagian diatas yaitu bendahara, Kepala Desa, badan permusyawaratan desa dan masyarakat di desa ploso kecamatan jombang yang menjadi lokasi penelitian. Dari hasil wawancara tersebut diperoleh beberapa temuan. Kepala Desa dan aparat desa belum begitu memahami tentang pencatatan akuntansi desa dari target kegiatan yang ditetapkan hingga realisasi kegiatan tersebut. Hal ini menunjukkan bahwa aparat desa belum begitu memahami terkait dengan segala pencatatan akuntansi desa, meskipun aparat desa telah dibekali dengan berbagai pelatihan terkait pengelolaan keuangan desa. Disamping itu, hal ini juga menimbulkan kekhawatiran dari masyarakat terkait dengan adanya program dana desa yang telah masuk. Karena mereka berpendapat bahwa dalam pengelolaan keuangan desa masih terkesan asal-asalan apalagi kalau dana desa sudah masuk, maka tentu yang dikhawatirkan mereka adalah tentu hal ini akan menjadi lumbung korupsi yang baru. 
Selain itu, Kekurangsiapan dan kecemasan hal itu disebabkan minimnya sosialisasi dan bimbingan dari pemerintah kabupaten Jombang. Seluruh Kepala Desa dan aparat desa inginnya laporan pengelolaan keuangan desa diseragamkan terlebih dahulu dengan dituangkan peraturan tersendiri mulai dari pencatatan akuntansi hingga menjadi pelaporan informasi keuangan yang sesuai dengan standar akuntansi pemerintahan. Sehingga apabila program dana desa tersebut, tentunya para Kepala Desa dan aparat desa tidak kebingungan dalam menyusun pencatatan akuntansi dan pelaporannnya.

\section{Pengelolaan keuangan desa}

Secara adminstratif berdasarkan data statistik kabupaten Jombang pada tahun 2015 terdiri dari 18 Kecamatan dan 322 Desa serta 31 Kelurahan. Desa Ploso adalah salah satu desa yang berada di kecamatan Jombang. Desa Ploso memiliki luas $155.873 \mathrm{Ha}$, jumlah penduduk 8.490 Jiwa dan kepadatan penduduk 300 per Km. Susunan organisasi pemerintahan Desa Ploso terdiri dari 12 orang dengan Kepala Desa Sri Udjiati. Kepala Desa pada dasarnya bertanggung jawab kepada Camat Jombang. Disamping itu juga bertanggung jawab untuk memberikan keterangan laporan pertanggung jawaban kepada rakyat desa yang dipimpinnya serta memberikan peluang dan kesempatan kepada masyarakat desa melalui Badan Permusyawaratan Desa ( BPD) untuk menampung aspirasi masyarakat desa.

Anggaran pendapatan dan belanja desa kadangkala cenderung tidak seimbang antara pendapatan dan pengeluaran. Realitanya, hal ini disebabkan oleh empat faktor utama yaitu sebagai berikut (Hudayana \& FPPD dalam Subroto, 2009).

1. Desa wajib memiliki anggaran pendapatan dan belanja yang kecil dan sumber pendapatannya sangat tergantung pada bantuan yang sangat kecil pula.

2. Tingkat kesejahteraan masyarakat terlalu rendah.

3. Rendahnya dana operasional desa untuk menjalankan pelayanan.

4. Banyaknya program pembangunan masuk ke desa tetapi pengelolaan dilakukan oleh dinas terkait.

Siklus penyusunan keuangan desa terbagi menjadi 3 (tiga) yaitu sebagai berikut (data Desa Ploso, 2017):

1. Bulan November sampai Desember :Penyusunan siklus tahunan desa.

2. Bulan Oktober : Perubahan anggaran. 
3. Bulan Januari sampai Maret : Penyampaian laporan pertanggung jawaban.

Sesuai dengan Peraturan Bupati Jombang nomor 6 Tahun 2017 tentang pedoman pengeloaan keuangan desa, menyatakan bahwa sekretaris desa bertindak sebagai koordinator pelaksana teknis pengelolaan keuangan desa. Dalam menjalankan fungsi tersebut, maka sekretaris desa mempunyai tugas untuk :

a. Menyusun dan melaksanakan kebijakan pengelolaan APB Desa.

b. Menyusun rancangan peraturan desa tentang APB Desa, perubahan APB Desa dan pertanggung jawaban pelaksanaan APB Desa.

c. Melakukan pengendalian terhadap pelaksanaan kegiatan yang telah ditetapkan dalam APB Desa.

d. Menyusun pelaporan dan pertanggungjawaban pelaksanan APB Desa, dan

e. Melakukan verifikasi terhadap bukti -bukti penerima dan pengeluaran APB Desa.

Selain itu, sekretaris desa kemudian menyampaikan dan menjelaskan rancangan peraturan desa kepada Kepala Desa untuk memperoleh persetujuan. Kepala Desa menyampaikan rancangan peraturan desa kepada BPD paling lambat minggu pertama bulan Nopember pada tahun anggaran sebelumnya, untuk dibahas bersama. Peraturan Desa yang sudah dirancang tentang APB Desa yang telah disetujui bersama dengan BPD disampaikan paling lama 3 hari kepada Camat untuk dilakukan pengkajian dan penelitian apakah sudah sesuai dengan peraturan perundang-undangan yang berlaku. Pengkajian dan penelitian oleh Camat dan penyampaian rekomendasi Camat kepada Bupati dilakukan paling lambat 6 hari sejak diterimanya APB Desa. Bupati menetapkan hasil evaluasi rancangan APB Desa paling lambat 15 hari sejak diterimanya rancangan APB Desa yang dikirim oleh Camat. Apabila Bupati tidak memberikan hasil evaluasi sampai dengan batas waktu atas persetujuan tersebut, kepala desa dapat menetapkan rancangan peraturan desa tentang APB Desa menjadi peraturan desa.

Contoh siklus tahunan Desa Ploso tahun anggaran 2016 (daftar peraturan-peraturan Desa Ploso).

1. APB Desa Ploso tahun 2016.

2. Pengelolaan tanah kas desa.

3. Pungutan desa 
4. Pemanfaatan dan pemeliharaan saran dan prasarana Pendidikan anak usia dini.

5. Pertanggung jawaban APB Desa tahun 2015 dan lain-lain.

6. Perubahan APB Desa tahun 2016.

Contoh siklus tahunan desa Ploso tahun 2016 (Keputusan-keputusan Kepala Desa Ploso).

1. Rencana kegiatan pembangunan Desa Ploso tahun 2017.

2. Pembentukan tim pelaksana distribusi beras untuk rumah tangga miskin.

3. Pelaksana kegiatan alokasi dana desa.

4. Pembentukan tim pelaksana pendataan (updating \& validasi data KB) dan lain-lain.

Peraturan Pemerintah nomor 72 tahun 2005 pasal 67 menjelaskan bahwa penyelenggaraan urusan pemerintahan desa didanai dari anggaran pendapatan dan belanja desa, bantuan pemerintah dan bantuan pemerintah daerah.

Peraturan Bupati Jombang nomor 06 tahun 2017 tentang perubahan atas peraturan Bupati nomor 27 tahun 2015 tentang pedoman pengelolaan keuangan desa pada bagian kesatu pasal 8, menjelaskan bahwa APBDesa terdiri atas : pendapatan desa, belanja desa dan pembiayaan desa. Peraturan Bupati Jombang nomor 06 tahun 2017 pasal 9 ayat 1 mendefinisikan pendapatan desa yang selanjutnya disebut pendapatan adalah semua penerimaan yang melalui rekening desa yang wajib diterima oleh pemerintah desa dalam jangka waktu 1 (satu) tahun anggaran yang tidak perlu dibayar kembali oleh desa. Pendapatan Desa Ploso kecamatan Jombang tahun 2016 berasal dari pendapatan asli desa, bagi hasil pajak daerah, bagi hasil restribusi daerah, bagi hasil desa dari dana perimbangan dari pemerintah daerah, bantuan keuangan dari pemerintah daerah (provinsi, kabupaten dan desa lainnya), dan lain-lain pendapatan yang sah. Total pendapatan pada tahun 2016 sebesarRp 2.400.000.000,00 (dua milyar empat ratus juta rupiah). Pendapatan terbesar berasal dari pencairan dana desa yang merupakan program dari pemerintah pusat sebesar Rp 1.000.000.000,00 (satu milyar rupiah) kemudian disusul dari hasil alokasi dana desa sebesar Rp 700.000.000,00 (tujuh ratus juta rupiah). Desa Ploso tidak memperoleh pendapatan yang bersumber dari bagian laba BUM-Desa, tanah kas desa, sewa bangunan milik desa, Bunga simpanan bank,bantuan keuangan khusus,hibah dan sumbangan pihak ketiga. 
Desa Ploso untuk tahun-tahun berikutnya perlu mencari sumber-sumber pendapatan lain. Misalnya mendirikan BUM-Desa sehingga pendapatan meningkat dan dapat meningkatkan perekonomian masyarakat setempat. Hasil kekayaan alam (garapan) di Desa Ploso untuk saat ini tidak bisa hanya mengandalkan dari sektor pertanian, oleh sebab itu desa perlu merencanakan bangunan (kios atau toko) untuk disewakan. Pertimbangan merencakan bangunan untuk disewakan mengingat sebagian tanah kas desa di wilayah yang strategis untuk melakukan usaha (bisnis).

Peraturan Bupati Jombang nomor 06 tahun 2017 pasal 12 ayat 1 mendefinisikan belanja desa yang selanjutnya disebut belanja adalah semua pengeluaran dari rekening desa yang melalui Rekening desa.Sedangkan dalam penggunaannya belanja desa terdiri dari beberapa ketentuan yaitu :

a. Paling sedikit $70 \%$ (tujuh puluh perseratus) dari jumlah anggaran belanja desa digunakan untuk mendanai penyelenggaraan pemerintahan desa, pelaksanaan pembangunan desa, pembinaan kemasyarakatan desa dan pemberdayaan masyarakat desa.

b. Paling banyak 30\% (tiga puluh perseratus) dari jumlah anggaran belanja desa digunakan untuk :

1. Penghasilan tetap dan tunjangan kepala desa dan perangkat Desa.

2. Operasional pemerintah desa.

3. Tunjangan dan operasional Badan Permusyawaratan Desa,

4. Insentif rukun tetangga dan rukun warga.

Belanja Desa Ploso tahun 2016 adalah sebesar Rp 2.350.000.000,00 ( Dua milyar tiga ratus lima puluh juta rupiah) yang sebagian besar digunakan untuk belanja langsung yang terdiri dari belanja barang dan jasa, belanja bahan modal, belanja perbaikan saluran irigasi, belanja pengaspalan jalan desa, dan belanja tidak langsung yaitu belanja pegawai, tunjangan, belanjan operasional kepala desa, perangkat desa \& BPD, belanja bantuan sosial, belanja bantuan keuangan dan belanja tidak terduga. Desa Ploso tidak melakukan belanja sewa alat berat, belanja tambahan penghasilan, belanja subsidi \& belanja hibah.

Dari Laporan Realisasi Anggaran Pendapatan dan Belanja Desa Pemerintahan Desa Ploso Tahun anggaran 2016, belanja paling besar adalah belanja modal pelaksanaan 
pembangunan desa sebesar $\mathrm{Rp}$ 1.008.000.000,00 kemudian belanja modal penyelenggaraan pemerintah desa sebesar Rp 720.000.000,00 (tujuh ratus dua puluh juta rupiah), belanja lain-lain $\mathrm{Rp}$ 622.000.000,00 (enam ratus dua puluh dua juta rupiah). Sebelum berlakunya UU no. 6 tahun 2014, Pemerintah Desa dalam rangka peningkatan infrastruktur desa selalu mengajukan proposal ke pengusaha-pengusaha swasta baik yang berada dalam lingkup areal wilayah desa ploso maupun diluar areal wilayah desa Ploso, namun sejak diberlakukannya program dana desa yang merupakan program dari pemerintah pusat, belanja pembangunan desa terlihat begitu siginifikan dan sangat terasa dampaknya bagi kelangsungan hidup masyarakat desa Ploso.

Sedangkan berbicara tentang pembiayaan telah tertuang dalam peraturan Bupati Jombang nomor 06 tahun 2017 bahwa pembiayaan adalah semua penerimaan yang perlu dibayar kembali dan /atau pengeluaran yang akan diterima kembali,baik pada tahun anggaran yang bersangkutan maupun pada tahun-tahun anggaran berikutnya. Pembiayaan desa terdiri atas : Penerimaan pembiayaan dan pengeluaran pembiayaan. Untuk penerimaan pembiayaan desa mencakup :

a. Sisa lebih perhitungan anggaran (silPA) tahun sebelumnya.

b. Pencairan dana cadangan.

c. Hasil penjualan kekayaan desa yang dipisahkan

d. Penerimaan pinjaman desa.

Sedangkan untuk pengeluaran pembiayaan desa terdiri dari :

a. Pembentukan dana cadangan

b. Penyertaan modal Desa

c. Pembayaran pokok utang.

Desa Ploso penerimaan pembiayaan sebesar Rp 25.000.000,00 dari hasil kekayaan desa yang dipisahkan.

Dari Pencatatan laporan keuangan pada Pemerintahan Desa Ploso, terlihat bahwa pencatatan sistem akuntansi yang digunakan di Desa Ploso Kecamatan Jombang menggunakan sistem akuntansi kas, ini menunjukkan bahwa pada tingkat desa pencatatan akuntansi masih sangat sederhana. Peraturan Bupati Jombang nomor 06 tahun 2017 tentang keuangan desa menyebutkan bahwa anggaran pendapatan dan belanja harus 
didukung dengan bukti yang lengkap dan sah dan dimasukkan di rekening desa atas nama pemerintah desa. Penerapan sistem akuntansi berbasis kas bertentangan dengan permendagri nomor 64 tahun 2013 yang mewajibkan pemerintah sektor publik menerapkan sistem akuntansi berbasis akrual. Keterbatasan sumber daya manusia di desa menyebabkan desa tidak secepat sektor-sektor yang lain dalam mengimplementasi undang-undang dan peraturan menteri.

Sedangkan pada basis kas yang telah berjalan memiliki beberapa manfaat dan kelemahan dalam penerapannya. Manfaat -manfaat penerapan basis kas, yaitu sebagai berikut :

1. Prinsip -prinsip yang mendasari basis kas sederhana mudah untuk dipahami dan dijelaskan.

2. Pelaporan yang mungkin lebih cepat karena mengompilasikan informasi yang didasarkan dengan basis kas relatif lebih mudah untuk dilakukan.

3. Pelaksanaan sistem akuntansi berbasis kas untuk menyiapkan laporan keuangan berbasis kas tidak terlalu memerlukan personel yang terlatih.

4. Personel yang melaksanakan sistem akuntansi berbasis kas tidak perlu melakukan pertimbangan untuk menentukan jumlah arus kas pada periode berjalan.

5. Mudah bagi berbagai pengguna laporan keuangan untuk mengakses dan memahami informasi yang ada karena akuntansi kas tidak membutuhkan pengetahuan akuntansi yang rinci.

Kelemahan-kelemahan penerapan basis kas, yaitu sebagai berikut :

1. Tidak dapat menyediakan informasi yang terkait dengan asset, kewajiban dan dampak dari konsumsi sumber daya pada periode berjalan.

2. Mengabaikan arus sumber daya lainnya yang mungkin memiliki dampak atas kemampuan pemerintah untuk menyediakan barang dan jasa di saat ini dan di masa yang akan datang.

3. Tidak mencatat manfaat-manfaat yang diperoleh dari asset selama periode berjalan.

4. Tidak menyediakan informasi yang terkait dengan modal (aset).

5. Membatasi publik untuk menilai akuntabilitas pemerintah dalam penggunaan sumber daya yang ada. 
Melihat dari batasan manfaat dan kelemahan dari penerapan basis kas diatas, sangatlah tidak relevan apabila penggunaan basis ini tetap digunakan untuk dimasa yang akan datang. Hal ini sejalan dengan begitu banyaknya program-program kegiatan pembangunan desa, seperti program dana desa yang merupakan program dari pemerintah pusat. Tentunya dengan masih dilaksanakannya basis kas ini, tidak tertutup kemungkinan adanya penyelewengan penggunaan dana keuangan desa yang harus dilaporkan oleh aparat desa.

Dari data hasil wawancara dan observasi pendahuluan, dapat dijelaskan bahwa ada ketidaksiapan kepala desa dan aparatnya yang lebih disebabkan karena masalah teknis, misalnya minimnya sosialisasi, bimbingan dan rendahnya kemampuan di bidang penatausahan keuangan serta pelaporannya. Hal ini juga sebagai imbas dari penerapan basis kas yang digunakan oleh aparat desa dalam pelaporan akuntansi pengelolaan keuangan desa yang tidak membutuhkan pengetahuan akuntansi yang lebih rinci.

Tabel 1.

Target dan Realisasi Pendapatan Desa Ploso Tahun 2012-2016

\begin{tabular}{|c|c|r|c|c|}
\hline \multirow{2}{*}{ No } & \multirow{2}{*}{ Tahun } & \multicolumn{3}{|c|}{ Pendapatan } \\
\cline { 3 - 5 } & & \multicolumn{1}{|c|}{ Target } & Realisasi & Lebih (kurang) \\
\hline 1 & 2012 & $1,048,446,685$ & $1,289,047,311$ & $240,600,626$ \\
\hline 3 & 2013 & $694,892,798$ & $1,135,998,723$ & $441,105,925$ \\
\hline 4 & 2014 & $814,037,309$ & $1,128,924,724$ & $314,887,415$ \\
\hline 5 & 2015 & $1.951,421,081$ & $2,227,808,693$ & $276,387,612$ \\
\hline 6 & 2016 & $2,400,000,000$ & $2,525,000,000$ & $125,000,000$ \\
\hline
\end{tabular}

Sumber : Laporan RAPB Desa Ploso TA 2016

Pada tahun 2012 Desa Ploso menargetkan pendapatan sebesar Rp 1.048.446.685,00, namun pada realisasinya mencapai sebesar $\mathrm{Rp} 1.289 .047 .311,00$ dan kelebihan pendapatan sebesar Rp 240.600.626,00. Kelebihan pendapatan juga terjadi pada tahun 2013 sebesar Rp 441.105.925,00, tahun 2014 sebesar Rp 314.887.415,00, tahun 2015 sebesar Rp 276.387.612,00, dan tahun 2016 terjadi kelebihan pendapatan sebesar Rp 125.000.000,00. Rata-rata kelebihan pendapatan didominasi pada kenaikan pendapatan hasil usaha, dan bantuan keuangan dari pemerintah. Namun semenjak diberlakukannya program pendapatan dana desa dari pemerintah pusat yang dimana tiap desa mendapat 
bantuan program dana desa sebesar Rp 1 milyar per desa, pemerintah desa Ploso menaikkan target pendapatannya secara signifikan.

Tabel 2.

Target dan Realisasi Belanja Desa Ploso Tahun 2012-2016

\begin{tabular}{|c|c|r|r|r|}
\hline \multirow{2}{*}{ No } & \multirow{2}{*}{ Tahun } & \multicolumn{3}{|c|}{ Pendapatan } \\
\cline { 3 - 5 } & & Target & Realisasi & Lebih (kurang) \\
\hline 2 & 2012 & $870,142,430$ & $1,193,496,257$ & $323,353,827$ \\
\hline 3 & 2013 & $1,058,811,900$ & $1,165,273,725$ & $106,461,825$ \\
\hline 4 & 2014 & $791,024,250$ & $1,109,121,753$ & $318,097,503$ \\
\hline 5 & 2015 & $826,783,750$ & $1,125,673,882$ & $298,890,132$ \\
\hline 6 & 2016 & $2,350,000,000$ & $2,414,000,000$ & $64,000,000$ \\
\hline
\end{tabular}

Sumber : Laporan RAPB Desa Ploso TA 2016

Tahun 2012 target belanjan Desa Ploso sebesar Rp 870.142.430 realisasi belanja sebesar Rp 1.193.496.257, dengan selisih belanja tahun 2012 menjadi sebesar Rp 323.353.827. Tahun 2013 target Rp 1.058.811.900 realisasi sebesar Rp 1.165.273.725, tahun 2014 target sebesar $\mathrm{Rp} 791.024 .250$ realisasi sebesar Rp 1.109.121.753, tahun 2015 target sebesar Rp 826.783.750, realisasi sebesar Rp 1.125.673.882 dan tahun 2016 target sebesar $\mathrm{Rp}$ 2.350.000.000, realisasi sebesar Rp 2.414.000.000

Dalam menilai kinerja APB Desa, pada umumnya dilihat pada sisi pendapatan dan belanja. Apabila pada pendapatan antara yang direncanakan dengan yang direalisasikan lebih besar yang direalisasikan, maka kinerja pendapatan dapat dikatakan baik. Tetapi, bisa saja realisasi pendapatan lebih kecil dibanding rencana pendapatan dapat dikatakan baik apabila pendapatan tersebut terkait dengan pungutan mengenai kesehatan masyarakat desa. Pada belanja, pada umumnya realisasi belanja lebih kecil dibanding rencana belanja, maka dapat dikatakan dengan baik. Tetapi bisa saja realisasi belanja lebih besar dibanding yang direncanakan dapat dikatakan baik, apabila belanja tersebut digunakan untuk belanja barang/jasa dan belanja modal atau belanja untuk kepentingan jangka panjang, semisal untuk belanja pendidikan dan kesehatan.

Bulan Januari sampai dengan bulan Maret pemerintahan desa wajib melaporkan pertanggungjawabannya kepada Bupati melalui Camat. Format Laporan pertanggung jawaban APB Desa sesuai dengan Lampiran Peraturan Menteri Dalam Negeri no. 113 tahun 
2014 disertai dengan peraturan bupati Jombang no. 07 tahun 2017 tentang pedoman pengelolaan keuangan desa bahwa laporan pertanggung jawaban harus disertai dengan buku kas umum, buku kas pembantu perincian objek penerimaan/buku kas pembantu perincian objek pengeluaran dan buku kas harian pembantu. Laporan keuangan sebagai output keuangan desa dapat menggambarkan kegiatan-kegiatan selama 1 tahun anggaran dan disampaikan kepada pihak terkait termasuk masyarakat. Adanya laporan keuangan tersebut masyarakat diharapkan untuk mengevaluasi dan memberikan kontribusi perbaikan di masa depan.

\section{Tantangan Dengan Adanya UU Nomor 06 Tahun 2014 Tentang Desa}

Sejak digulirkannya dan ditetapkannya RUU Desa menjadi UU Desa oleh Pemerintah dan DPR pada tahun 2014, terjadi perubahan yang signifikan terhadap kemajuan pembangunan desa. Salah satu perubahan yang dinanti adalah semakin banyaknya dana dari pemerintah pusah yang akan mengucur ke tingkat desa. Hal ini merupakan suatu harapan agar pembangunan desa dapat lebih maju dan terciptalah pemerataan pembangunan didaerah dan antara kota dan desa. Namun, kebijakan ini harus diiringi dengan pengelolaan keuangan desa yang transparan dan akuntabel agar dampak kebijakan tersebut dapat tepat sasaran dan dirasakan oleh masyarakat desa.

Salah satu perubahan dengan adanya UU Desa yang baru tersebut adalah sebagai berikut :

1. Bertambahnya sumber pendapatan desa. Dalam UU nomor 6 tahun 2014 tersebut, sumber pendapatan desa ditambah dua sumber pendapatan, yaitu sumber pendapatan dari alokasi APBN dan lain-lain pendapatan desa yang sah. Besaran alokasi anggaran yang peruntukannya langsung ke desa ditentukan 10\% dari dan diluar dana transfer daerah secara bertahap.

2. Berubahnya formulasi perhitungan bagi hasil pajak, restribusi dan ADD. Bagian hasil pajak dan retribusi daerah kabupaten/kota sepuluh persennya diperuntukkan untuk desa. Sedangkan ADD besarannya paling sedikit 10\% dari dana perimbangan yang diterima Kabupaten/Kota dalam APBD setelah dikurangi Dana Alokasi Umum.

3. Perlindungan terhadap implementasi ADD. Dalam UU Desa yang baru disebutkan bahwa Pemerintah Kabupaten/kota yang tidak memberikan alokasi ADD maka pemerintah 
pusat akan melakukan penundaan dan/atau pengurangan sebesar alokasi dana perimbangan setelah dikurangi Dana Alokasi Khusus yang seharusnya disalurkan ke desa. Dengan adanya aturan tersebut diharapkan pemerintah kabupaten/kota akan serius menangani dan menyelenggarakan ADD.

Ketiga perubahan tersebut menyiratkan bagi pemerintah dan berbagai pihak untuk segera menyusun rumusan kebijakan yang mengatur pedoman pengelolaan keuangan desa. Begitu besarnya alokasi dana yang akan didapatkan oleh desa memberikan angin segar bagi di sisi lain juga perlu diiringi dengan aturan teknis yang mengatur pengelolaan keuangan desa yang transparan dan akuntabel.

\section{Kesimpulan}

Berdasarkan dari uraian penelitian diatas, dapat dikemukakan beberapa kesimpulan bahwa dari hasil penelitian yang dilakukan oleh peneliti, menyiratkan bahwa aparat desa belum memiliki kesiapan dalam melaksanakan Undang-undang nomor 6 tahun 2014. Mereka belum memahami sepenuhnya pengelolaan keuangan desa.Hal ini diperparah lagi dengan rendahnya kualitas sumber daya manusia, minimnya sosialisasi dan bimbingan. Laporan keuangan di Pemerintahan Desa Ploso masih menggunakan basis kas diharapkan tahun berikutnya menggunakan basis akrual dengan dukungan dari pelatihan sumber daya manusia dan pendampingan dari pemerintah daerah guna penyesuaian perubahan perundangan-undangan.

\section{Daftar Pustaka}

Akbar, B. 2011. Akuntabilitas Publik dan Peran Akuntansi Keuangan Daerah Pada Pemerintah Daerah. Avalaible at https : //pekikdaerah.wordpress.com.

Aliyah, S., dan A. Nahar. 2012. Pengaruh Penyajian Laporan Keuangan Daerah Dan Aksesibilitas Laporan Keuangan Daerah Terhadap Transparansi Dan Akuntabilitas Pengelolaan Keuangan Daerah Kabupaten Jepara. Jurnal Akuntansi \& Auditing. Vol.8 No.2:97-189.

Fatihuddin, Didin. 2012. Metode Penelitian Untuk Ilmu Ekonomi, Manajemen dan Akuntansi : dari Teori ke Praktek. Surabaya : PPs UM Surabaya. 
Furqani, A. 2010. Pengelolaan Keuangan Desa Dalam Mewujudkan Good Governance (Studi Pada Pemerintahan Desa Kalimo'ok Kecamatan Kalianget Kabupaten Sumenep). Tesis. Surabaya: UPN Jatim.

Harun. 2007. Obstacle to Public Sector Accounting Reform in Indonesia. Buletin of Indonesia Economics Studies,43 (3) : 365 -376.

Kindarsih, L. 2008. Faktor-Faktor yang Mempengaruhi Kualitas Anggaran Pendapatan dan Belanja Sekolah (APBS) SMA Negeri di Yogyakarta. Tesis Mahasiswa Program pasca sarjana Universitas Gajah Mada.

Peraturan Menteri Dalam Negeri No. 113 tahun 2014 tentang Pedoman Pengelolaan keuangan Desa.

Peraturan Bupati Jombang No.07 tahun 2017 tentang Pedoman Pengelolaan Keuangan Desa.

Sadjiarto, A. 2000. Akuntabilitas dan Pengukuran Kinerja Pemerintahan. Jurnal Akuntansi dan Keuangan, Vol. 2 No.2:138-150.

Tanjung, A.H. 2000. Akuntansi, Transparansi dan Akuntabilitas Keuangan Publik. Available at https : // swamandiriwordpress.com.

Undang -Undang Republik Indonesia No. 06 Tahun 2014 tentang Desa.

Yahya, I. 2006. Akuntabilitas dan Transparansi Pengelolaan Keuangan Daerah. Jurnal Sistem Teknik Industri. Vol 7 No. 4 : 27-29.

Yuliani, S.,Nadirsyah, dan U. Bakar. 2010. Pengaruh Pemahaman Akuntansi, Pemanfaatan Sistem Informasi Akuntansi Keuangan Daerah dan Peran Internal Audit Terhadap Kualitas Laporan Keuangan Pemerintah Daerah. Jurnal Telaah dan Riset Akuntansi. Vol. 3 No. 2 :206 -220. 


\section{Lampiran}

\section{Realisasi Anggaran Pendapatan dan Belanja Desa \\ Pemerintah Desa Ploso Kecamatan Ploso-Jombang \\ Tahun Anggaran 2016}

\begin{tabular}{|c|c|c|c|c|}
\hline $\begin{array}{c}\text { Kode } \\
\text { Rekening }\end{array}$ & Uraian & $\begin{array}{c}\text { Anggaran } \\
(\mathrm{Rp})\end{array}$ & $\begin{array}{c}\text { Realisasi } \\
\text { ( Rp) }\end{array}$ & $\begin{array}{c}\text { Selisih } \\
(\%)\end{array}$ \\
\hline 1 & PENDAPATAN & & & \\
\hline 1.1 & Pendapatan Asli Desa & $370,000,000$ & $430,000,000$ & $16 \%$ \\
\hline 1.1 .1 & Hasil Usaha & $250,000,000$ & $300,000,000$ & $20 \%$ \\
\hline 1.1 .2 & Swadaya,Partisipasi dan Gotong Royong & $90,000,000$ & $100,000,000$ & $11 \%$ \\
\hline 1.1 .3 & Lain-lain Pendapatan Asli Desa Yang sah & $30,000,000$ & $30,000,000$ & $0 \%$ \\
\hline 1.2 & Pendapatan Transfer & $1,965,000,000$ & $2,020,000,000$ & $3 \%$ \\
\hline 1.2 .1 & Dana desa & $1,000,000,000$ & $1,000,000,000$ & $0 \%$ \\
\hline 1.2 .2 & $\begin{array}{l}\text { Bagian hasil Pajak dan Retribusi Kabupaten / } \\
\text { Kota }\end{array}$ & $65,000,000$ & $70,000,000$ & $7.69 \%$ \\
\hline 1.2 .3 & Alokasi Dana Desa & $700,000,000$ & $700,000,000$ & $0 \%$ \\
\hline 1.2 .4 & Bantuan Keuangan & & & \#DIV / 0 ! \\
\hline 1.2.4.1 & Bantuan Provinsi & $150,000,000$ & $175,000,000$ & $17 \%$ \\
\hline 1.2.4.2 & Bantuan Kabupaten / Kota & $50,000,000$ & $75,000,000$ & $50 \%$ \\
\hline 1.3 & Pendapatan lain-lain & $2,465,000,000$ & $2,600,000,000$ & $5 \%$ \\
\hline 1.3.1 & Hibah dan sumbangan pihak ketiga & $50,000,000$ & $60,000,000$ & $20 \%$ \\
\hline 1.3 .2 & Lain-lain Pendapatan Desa yang sah & $15,000,000$ & $15,000,000$ & $0 \%$ \\
\hline & JUMLAH PENDAPATAN & $2,400,000,000$ & $2,525,000,000$ & $5.2 \%$ \\
\hline 2 & BELANJA & & & \\
\hline 2.1 & Bidang Penyelenggaraan Pemerintah Desa & $720,000,000$ & $784,000,000$ & $8.9 \%$ \\
\hline 2.1 .1 & Penghasilan Tetap dan Tunjangan & & & \\
\hline 2..1.1.1 & Belanja Pegawai & $485,000,000$ & $524,000,000$ & $8 \%$ \\
\hline & - Penghasilan Tetap Kepala Desa dan Perangkat & $350,000,000$ & $350,000,000$ & $0 \%$ \\
\hline
\end{tabular}




\begin{tabular}{|c|c|c|c|c|}
\hline & - Tunjangan Kepala Desa dan Perangkat & $60,000,000$ & $78,000,000$ & $30 \%$ \\
\hline & - Tunjangan BPD & $60,000,000$ & $78,000,000$ & $30 \%$ \\
\hline & - Insentif RT dan RW & $15,000,000$ & $18,000,000$ & $20 \%$ \\
\hline 2.1 .2 & Operasional Perkantoran & $185,000,000$ & $200,000,000$ & $8 \%$ \\
\hline \multirow[t]{9}{*}{ 2.1.2.2 } & Belanja Barang dan Jasa & $95,000,000$ & $95,000,000$ & $0 \%$ \\
\hline & - Alat tulis Kantor & $9,500,000$ & $9,500,000$ & $0 \%$ \\
\hline & - Benda Pos & $4,750,000$ & $4,750,000$ & $0 \%$ \\
\hline & - Pakaian Dinas dan Atribut & $33,250,000$ & $33,250,000$ & $0 \%$ \\
\hline & - Alat dan Bahan kebersihan & $4,750,000$ & $4,750,000$ & $0 \%$ \\
\hline & - Perjalanan Dinas & $9,500,000$ & $9,500,000$ & $0 \%$ \\
\hline & - Pemeliharaan Barang & $9,500,000$ & $9,500,000$ & $0 \%$ \\
\hline & - Air,Listrik dan Telepon & $19,000,000$ & $19,000,000$ & $0 \%$ \\
\hline & - Honor & $4,750,000$ & $4,750,000$ & $0 \%$ \\
\hline \multirow[t]{4}{*}{ 2.1.2.3 } & Belanja Modal & $90,000,000$ & $105,000,000$ & $16.7 \%$ \\
\hline & - Komputer dan Printer & $75,000,000$ & $90,000,000$ & $20.0 \%$ \\
\hline & - Meja dan Kursi & $13,000,000$ & $13,000,000$ & $0 \%$ \\
\hline & - Mesin Tik & $2,000,000$ & $2,000,000$ & $0 \%$ \\
\hline 2.1 .3 & Operasional BPD & $50,000,000$ & $60,000,000$ & $20 \%$ \\
\hline \multirow[t]{4}{*}{ 2.1.3.2 } & Belanja barang dan Jasa & $50,000,000$ & $60,000,000$ & $20 \%$ \\
\hline & - Alat tulis kantor & $10,000,000$ & $12,000,000$ & $20 \%$ \\
\hline & - Penggandaan & $10,000,000$ & $15,000,000$ & $50 \%$ \\
\hline & - Konsumsi rapat & $30,000,000$ & $33,000,000$ & $10 \%$ \\
\hline 2.2 & Bidang Pelaksanaan Pembangunan Desa & $1,008,000,000$ & $1,008,000,000$ & $0.0 \%$ \\
\hline 2.2.1 & Perbaikan Saluran Irigasi & $604,800,000$ & $604,800,000$ & $0 \%$ \\
\hline 2.2.1.2 & Belanja Barang dan Jasa & $181,440,000$ & $181,440,000$ & $0 \%$ \\
\hline
\end{tabular}




\begin{tabular}{|c|c|c|c|c|}
\hline & - upah kerja & $163,296,000$ & $163,296,000$ & $0 \%$ \\
\hline & - honor & $18,144,000$ & $18,144,000$ & $0 \%$ \\
\hline \multirow[t]{3}{*}{ 2.2.1.3 } & Belanja Modal & $423,360,000$ & $423,360,000$ & $0 \%$ \\
\hline & - Semen & $169,344,000$ & $169,344,000$ & $0 \%$ \\
\hline & - material & $254,016,000$ & $254,016,000$ & $0 \%$ \\
\hline 2.2.2 & Pengaspalan Jalan Desa & $403,200,000$ & $403,200,000$ & $0 \%$ \\
\hline \multirow[t]{3}{*}{ 2.2.2.2 } & Belanja Barang dan Jasa & $120,960,000$ & $120,960,000$ & $0 \%$ \\
\hline & - Upah kerja & $108,864,000$ & $108,864,000$ & $0 \%$ \\
\hline & - Honor & $12,096,000$ & $12,096,000$ & $0 \%$ \\
\hline \multirow[t]{3}{*}{ 2.2.2.3 } & Belanja modal & $282,240,000$ & $282,240,000$ & $0 \%$ \\
\hline & - Aspal & $169,344,000$ & $169,344,000$ & $0 \%$ \\
\hline & - Pasir & $112,896,000$ & $112,896,000$ & $0 \%$ \\
\hline 2.3 & Bidang Pembinaan Kemasyarakatan & $300,000,000$ & $300,000,000$ & $0.0 \%$ \\
\hline 2.3.1 & kegiatan Pembinaan Ketentraman dan ketertiban & $300,000,000$ & $300,000,000$ & $0 \%$ \\
\hline \multirow[t]{4}{*}{ 2.3.1.1 } & Belanja barang dan jasa & $300,000,000$ & $300,000,000$ & $0 \%$ \\
\hline & - Honor pelatih & $133,000,000$ & $133,000,000$ & $0 \%$ \\
\hline & - Konsumsi & $99,800,000$ & $99,800,000$ & $0 \%$ \\
\hline & - Bahan Pelatihan & $67,200,000$ & $67,200,000$ & $0 \%$ \\
\hline 2.4 & Bidang Pemberdayaan Masyarakat & $347,000,000$ & $347,000,000$ & $0.0 \%$ \\
\hline 2.4.1 & kegiatan pelatihan Kepala Desa dan perangkat & $322,000,000$ & $322,000,000$ & $0 \%$ \\
\hline \multirow[t]{4}{*}{ 2.4.1.1 } & Belanja Barang dan Jasa & $322,000,000$ & $322,000,000$ & $0 \%$ \\
\hline & - Honor pelatih & $160,000,000$ & $160,000,000$ & $0 \%$ \\
\hline & - Konsumsi & $94,800,000$ & $94,800,000$ & $0 \%$ \\
\hline & - Bahan Pelatihan & $67,200,000$ & $67,200,000$ & $0 \%$ \\
\hline 2.5 & Bidang Tak Terduga & - & - & \#DIV / 0 ! \\
\hline
\end{tabular}




\begin{tabular}{|c|c|c|c|c|}
\hline 2.5 .1 & kegiatan Kejadian luar biasa & - & - & \#DIV/0! \\
\hline \multirow[t]{6}{*}{ 2.5.1.2 } & Belanja Barang dan Jasa & - & - & \#DIV/0! \\
\hline & - Honor tim & - & - & \#DIV/0! \\
\hline & - Konsumsi & - & - & \#DIV/0! \\
\hline & - Obat-obatan & - & - & 1 \\
\hline & JUMLAH BELANJA & $2,375,000,000$ & $2,439,000,000$ & $2.7 \%$ \\
\hline & SURPLUS/DEFISIT & $50,000,000$ & $111,000,000$ & $122.0 \%$ \\
\hline 3 & PEMBIAYAAN & & & \\
\hline 3.1 & penerimaan Pembiayaan & - & - & \#DIV/0! \\
\hline 3.1 .1 & Sisa Lebih Perhitungan Anggaran ( SILPA) & - & - & $\# \mathrm{DIV} / 0$ ! \\
\hline 3.1 .2 & Pencairan dana cadangan & - & - & $\# \mathrm{DIV} / 0$ ! \\
\hline \multirow[t]{2}{*}{3.1 .3} & Hasil kekayaan desa yang dipisahkan & $25,000,000$ & $25,000,000$ & $0.0 \%$ \\
\hline & JUMLAH PENERIMAAN PEMBIAYAAN & $25,000,000$ & $25,000,000$ & $0.0 \%$ \\
\hline 3.2 & Pengeluaran Pembiayaan & & & \#DIV $/ 0$ ! \\
\hline 3.2 .1 & Pembentukan dana cadangan & $25,000,000$ & $25,000,000$ & $0.0 \%$ \\
\hline \multirow[t]{4}{*}{ 3.2.2 } & penyertaan modal Desa & $25,000,000$ & $25,000,000$ & $0.0 \%$ \\
\hline & JUMLAH PENGELUARAN PEMBIAYAAN & $50,000,000$ & $50,000,000$ & $0.0 \%$ \\
\hline & PEMBIAYAAN NETTO & $(25,000,000)$ & $(25,000,000)$ & $0.0 \%$ \\
\hline & SILPA & $25,000,000$ & $86,000,000$ & $244.0 \%$ \\
\hline
\end{tabular}

